\title{
Transposition
}

Musique et Sciences Sociales

Hors-série 2 | 2020

Sound, Music and Violence

\section{Going Underground: The Politics of Free Music around 1968}

Going underground : politiques de la musique libre autour de 1968

\section{Timothy Scott Brown}

\section{(2) OpenEdition \\ 1 Journals}

\section{Electronic version}

URL: http://journals.openedition.org/transposition/4863

DOI: $10.4000 /$ transposition.4863

ISSN: 2110-6134

\section{Publisher}

CRAL - Centre de recherche sur les arts et le langage

\section{Electronic reference}

Timothy Scott Brown, « Going Underground: The Politics of Free Music around 1968 », Transposition [Online], Hors-série 2 | 2020, Online since 15 March 2020, connection on 16 April 2020. URL : http:// journals.openedition.org/transposition/4863; DOI : https://doi.org/10.4000/transposition.4863

This text was automatically generated on 16 April 2020

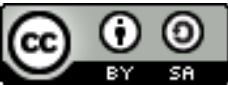

La revue Transposition est mise à disposition selon les termes de la Licence Creative Commons Attribution - Partage dans les Mêmes Conditions 4.0 International. 


\title{
Going Underground: The Politics of Free Music around 1968
}

Going underground : politiques de la musique libre autour de 1968

\author{
Timothy Scott Brown
}

\section{EDITOR'S NOTE}

The following is a commentary on: veLASCO-PUfLEAU Luis, "From Music to Armed Struggle, from 1968 to Action Directe: An Interview with Jean-Marc Rouillan", Transposition, no. Hors-série 2, 2020, https://journals.openedition.org/transposition/ 3780. DOI : https://doi.org/10.4000/transposition.3780

1 When Jean-Marc Rouillan observes that his "political commitment in 1968 was preceded by musical commitment", he touches on an oft-emphasized point in the recent scholarship on the "global 1960s". It was not just that culture and politics were intimately bound together around 1968, but that innovations in the former often precipitated developments in the latter. The point is particularly relevant where popular music is concerned. In no other area of cultural production was the social impact so explosive nor the politics of consumption so fraught. And as the scholarship of the last dozen or so years has shown and Rouillan's recollections again confirm, popular music-above all rock'n'roll-was the sound of revolt par excellence. Rouillan touches on this fact directly when he remarks that "[p]laying music was like going underground...in anticipation of a confrontation". That this statement could be uttered with reference to the moment of 1968 was in part a function of rock'n'roll's newness, and the ease with which that newness allowed it to articulate with other cultural and political innovations emerging around the same time. In this respect, rock'n'roll gained its cultural-political import through a process of synergy in which it came to stand in for a broader rebellion.

2 Rouillan's comment simultaneously suggests a spatial relationship-one in which the socially-valuable in music, as in politics, can take root only in the subterranean spaces 
where society's demands for conformity fail fully to penetrate. Here, the "underground" as a term/concept has a double valence-as the space simultaneously in which the left-wing political desperadoes of the post-' 68 moment marshaled their forces for all out war with the forces of the state, and the place where cultural militants sought to create authentic artistic expression free from the deforming pressures of mass commerce. The most culturally militant sounds, like the most politically militant agitation, were to be found not at the surface level of society, again, but underneath it, in the realm of subculture. To "go underground" was the act not just of the political militant who rejected all accommodation with bourgeois-parliamentary forms, but of the cultural militant who, similarly, rejected the forms dictated by the market.

3 The liberatory qualities of music, in Rouillan's account especially the music of Jimi Hendrix, foreshadowed other possibilities. With Hendrix, remembers Rouillan, "we felt that the door was open. What was not possible four years before, Jimi Hendrix said, 'It's possible now. We have decided that it's possible." This voluntaristic act was, as Rouillan puts it, a "decision", one that could lead to others. "From that point [the appearance on the scene of Hendrix] we could do whatever we wanted. Musically, he did what he wanted because he was capable of doing it. In the same way, as a political movement, we were fed up with political parties and unions. So we said to ourselves, "We're going to do things differently."

4 Almost as soon as it was enunciated, however, that emancipatory decision faced the danger of being rendered meaningless. "Jimi Hendrix would say 'I'm free' in a seven- or eight-minute solo;" says Rouillan; "Then, right away, people showed up to sell this freedom-major labels and concert managers. They played with this feeling of freedom, in order to sell it to our entire generation. They turned it into commercial products. We spent two or three years buying it, and then we thought, "No, we're getting fucked." The demand for free music was a response to this realization. A key threat perceived by radicals in the long 1960s was posed by what the Situationists dubbed recuperation, a term meant to invoke capitalism's ability to heal itself from challenges to its hegemony. Across the whole range of cultural production, from mainstream publishing programs calculated to cash in on the demand for the writings of Che and Mao to the commercesafe recapitulation of countercultural values represented by the musical Hair, capitalism proved adept at placing the revolution up for sale almost as quickly as it could be created. Radicals worried about recuperation because capitalism's ability to assimilate the cultural gave it the ability to disable the political. The "underground" in which subcultures flourished was never a pure sphere of rebellion, but constantly under threat of having its content siphoned away. Capitalism was all too adept, in the words of a band that figures centrally in Rouillan's account-the Clash-of "turning rebellion into money".

5 The effort to "free the music from the merchants" was a transnational one. It is no surprise, for example, that Action Directe's West German counterparts, the Movement 2nd June, were first politicized in precisely such a refusal of the logic of the "big concert". This was in the infamous 1965 riot at the Rolling Stones concert in West Berlin, which saw militants-to-be crash the show and participate in a riot that destroyed the venue. The same group of militants later carried out a smoke bomb attack on the West Berlin debut of Hair, denouncing it as an attempt to "gratify capitalist demands" at the expense of the "real subculture". The attack against Hair took place against the backdrop of ongoing police pressure against the Zodiak Arts Lab, 
a key site of subcultural experimentation in West Berlin. Such attempts to mobilize against the twin threat of police pressure and capitalist recuperation could be multiplied across a range of European and North American cases. Meanwhile the conceptual basis of these attempts-the assumption of a unity between political and cultural forms of struggle-was symbolized in an ubiquitous image of 1968 on both sides of the Atlantic: the juxtaposition of the machine gun and the electric guitar.

The pervasiveness of the association between political and cultural militancy and the linked struggle against recuperation offers more evidence of the importance of the transnational around 1968. It was not just a matter of ideas moving across national borders, however; rather, activists everywhere were responding to the issues imbedded in industrial society in general and capitalism in particular. That militants expected a political message from their music or ascribed political significance to music whether it was openly political or not was symptomatic of the long-1960s moment. But it also suggests for us a key link between the activism of the moment around 1968 and that of the decade that followed. It is no accident that Rouillan references both Hendrix and the Clash, the former a musical avatar of the 1960s rebellion, the latter the mostexplicitly political of the bands associated with the punk explosion of the late-1970s. In both cases, music held a political valence; more importantly, punk-along with the proto-punk exemplified by bands such as West Germany's Ton Steine Scherbendirectly embodied an approach to cultural production in which the act of making and distributing the music became as important as the messages embedded in the music itself.

7 This DIY ("Do it yourself") approach is a key feature linking the rebellion of 1968 and the rebellion of punk, calling into question too-easy assumptions about the extent to which punk actually broke with the cultural politics of a hippie rebellion that, on the surface, it violently rejected. More important is that DIY, as both mode of cultural production and political ethos, exists at the very heart of the particular understanding of music put forward by Jean-Marc Rouillan. The demand that music be free was simultaneously an anti-capitalist act and an act of cultural rebellion that sought to protect the integrity of the musical-political gesture. "Free music was a political struggle", as Rouillan puts it; "we understood it as such".

\section{ABSTRACTS}

Going Underground situates the demand for "free music" as part of a broader contestation of the terms of cultural consumption in the radical milieu of the long 1960s. At stake in the mobilizations recounted in the reflections of Action Directe-member Jean-Marc Rouillan was not just access to popular music, but the validity of the subversive meanings ascribed to cultural production under capitalism. Struggling with the system's ability to co-opt challenges to its hegemony by putting them up for sale, activists insisted that it was they, and not promoters or other financially-interested middle men, who had the right to determine the conditions under which liberatory cultural expression such as rock'n'roll would be consumed. The insistence that 
music be "free" embodied a characteristic demand of the radical moment around 1968: that culture actually matter.

Going underground resitue la revendication d'une "musique libre" (free music) au sein d'une contestation plus large, dans le milieu radical des années 1960, des termes de la consommation culturelle. Dans les mobilisations dont Jean-Marc Rouillan, membre d'Action directe, rend compte dans ses réflexions, ce qui est en jeu n'est pas simplement l'accès à la musique populaire, mais aussi la validité de la charge subversive accordée à la production culturelle en régime capitaliste. Luttant contre la capacité qu'a le système à intégrer - en le commercialisant - ce qui défie son hégémonie, les activistes insistent: c'est bien eux, et non des promoteurs et autres intermédiaires intéressés par l'argent, qui ont le droit de déterminer les conditions de consommation d'expressions culturelles libératoires telles que le rock'n'roll. L'insistance sur le fait que la musique doit être "libre" (free) rejoint une revendication caractéristique du moment radical entourant 1968 : que la culture compte bel et bien.

\section{INDEX}

Mots-clés: DIY, récupération, rock, subculture, underground

Keywords: DIY, recuperation, rock, subculture, underground

\section{AUTHOR}

\section{TIMOTHY SCOTT BROWN}

Timothy Scott Brown is Professor and Chair of History at Northeastern University, and Senior Fellow at the Institute for European Studies at the University of California, Berkeley. He is a recent Fellow of the American Council of Learned Societies and Berlin Prize Fellow of the American Academy in Berlin. His books include West Germany in the Global Sixties: The AntiAuthoritarian Revolt, 1962-1978 (Cambridge 2013); The Global Sixties in Sound and Vision: Media, Counterculture, Revolt (Palgrave 2014); and Between the Avantgarde and the Everyday: Subversive Politics in Europe, 1957 to the Present (Berghahn 2011). His latest book, Sixties Europe, is forthcoming with Cambridge University Press in 2020. 